Reprod. Nutr. Dévelop., 1983, 23 (5), 899-905.

\title{
A note on the metabolism of $5 \alpha$-androst-16-en-3-one in the young boar in vivo
}

M. BONNEAU, M. TERQUI (*)

Station de Recherches sur I'Elevage des Porcs, I.N.R.A., St-Gilles 35590 L'Hermitage, France.

(*) Station de Physiologie de la Reproduction, I.N.R.A., Nouzilly 37380 Monnaie, France.

Summary. The metabolism of plasma $5 \alpha$-androst-16-en-3-one (androstenone) was studied in two young boars weighing about $100 \mathrm{~kg}$ in which a single dose of tritiated androstenone was injected intravenously. The peripheral blood of one boar was continuously sampled for $6 \mathrm{~h}$ after injection; the total radioactivity per liter of plasma increased up to $14 \mathrm{~min}$ after the injection, and then declined rather slowly since plasma radioactivity was still measurable 7 days after injection. The metabolic clearance rate of androstenone was calculated to be about 80000 liters per day. This quick disappearance of plasma androstenone was probably mainly due to storage in fatty tissue and, to a lesser extent, to catabolism into $5 \alpha$-androst-16-en- $3 \alpha$-ol, $5 \alpha$-androst-16-en-3 $\beta$-ol and particularly into unknown more polar compounds of which there were at least three. Radioactivity was mainly eliminated in the urine in the form of the same unknown polar compounds.

\section{Introduction.}

Boar testis synthesizes high amounts of 16 unsaturated $C_{19}$ steroids $\left(C_{19} \Delta_{16}\right)$ from pregnenolone $\left({ }^{*}\right)$ and progesterone. The pathways of their biosynthesis are now well established in mature boar (Gower, 1972 ; Brophy and Gower, 1973, 1974 ; Shimizu and Nakada, 1976), although they are less known in young immature male pig (Mason et al., 1979). However, the subsequent metabolism of these compounds is still practically unknown. Indeed, few experiments have been devoted to the mechanisms by which circulating androstenone is stored in fatty tissue or to the pathways and intensity of its catabolism. In the mature boar, $\mathrm{C}_{19} \Delta_{16}$ steroids are probably catabolized in the liver (Claus, 1979 ; Fish et al., 1980) and subsequently eliminated in the uterine, mainly in the form of an- $\beta$ glucuronide (Gower et al., 1970 a, b ; Saat et al., 1972, 1974). The purpose of

(*) Abbreviations and trivial names : an- $\alpha$ : $5 \alpha$-androst-16-en- $3 \alpha$-ol ; an- $\beta$ : $5 \alpha$-androst-16-en-3 $\beta$ ol ; androstenone : $5 \alpha$-androst-16-en-3-one; pregnenolone : 5-pregnen-3 $\beta$-ol-20-one ; progesterone : 4-pregnen-3, 20-dione ; $\left({ }^{H} H\right)$ androstenone : $\left(5 \alpha^{-3} H\right) 5 \alpha$-androst-16-ene-3-one. 
this experiment was to study the metabolism and excretion of circulating androstenone in the young boar weighing about $100 \mathrm{~kg}$ (common slaughter weight).

\section{Material and methods.}

Steroids. - The tritiated and unlabelled forms of androstenone were the generous gifts of Dr. Hafferl (Institute of Organic Chemistry Synthex, Palo Alto, USA) and of Dr. C. L. Hewitt (Organon Laboratories, Newhouse, Scotland), respectively. The other steroids were purchased commercially.

Experimental design. - Ten $\mathrm{ml}$ of a solution of $\left(5 \alpha^{-}{ }^{3} \mathrm{H}\right)$ androstenone was injected intravenously in two young Large White boars weighing $97 \mathrm{~kg}$ (boar $\mathrm{A}$ : $115 \mu \mathrm{Ci}$ ) and $99 \mathrm{~kg}$ (boar $\mathrm{B}:<130 \mu \mathrm{Ci}$ ). The urine and faeces were collected every day during the week following injection. The peripheral venous blood of boar A was collected continuously through a catheter inserted into the external jugular vein from one min before to $6 \mathrm{~h}$ after $\left({ }^{3} \mathrm{H}\right)$ androstenone injection. A blood sample was then drawn every day during the following week.

Extraction of steroids. - Unconjugated steroids in plasma from boar $A$ and urine from boar $B$ were extracted with $2 \times 10$ volumes of hexane followed by $2 \times 10$ volumes of cyclohexane-ethyl-acetate $(1 / 1)$. Such a procedure ensures an androstenone extraction yield higher than $85 \%$ (Claus, 1979 ; Carrié and Bonneau, unpublished observations).

Plasma (or urine) samples were then incubated overnight at $37^{\circ} \mathrm{C}$ in a solution of $5 \%$ Helix pomatia hepatopancreatic juice secretion (IBF, France) adjusted to $\mathrm{pH} 4.8$ in order to hydrolize the conjugated steroids. These steroids were then extracted with $2 \times 10$ volumes of cyclohexane-ethylacetate $(1 / 1)$. The extraction yield of radioactivity from the hydrolized samples was about $50 \%$.

The radioactivity of faeces from boar $A$ was measured after extraction with a mixture of methanol and water (1/1).

Chromatography of steroids. - Column chromatography on hydroxyalkoxypropyl-Sephadex (lipidex TM ; Packard Instruments) was performed as suggested by Bicknell and Gower (1975). The samples were applied at the top of the column in $2 \times 1.75 \mathrm{ml} \mathrm{2-2-4-trimethyl-pentane} \mathrm{(fraction} 0$ ). Elution was carried out with $8 \times 2 \mathrm{ml} \mathrm{2-2-4-trimethyl-pentane} \mathrm{(fractions} 1$ to 8 ), $11 \times 2 \mathrm{ml} \mathrm{2-2-4-}$ trimethyl-pentane benzene (95/5) (fractions 9 to 19 ) and $10 \mathrm{ml}$ methanol (fraction 20). Androstenone, an- $\alpha$ and an- $\beta$ were obtained in fractions 2 to 5,10 to 13 and 13 to 16 , respectively. The more polar compounds were collected in fraction 20 .

Calculation of metabolic clearance rate of plasma androstenone. - The metabolic clearance rate (MCR) of plasma androstenone was first calculated according to the definition : MCR $=1 / \int_{0}^{\infty} \chi(\mathrm{t}) \mathrm{dt}$, where $\chi(\mathrm{t})$ was plasma $\left({ }^{3} \mathrm{H}\right)$ androstenone (as the $\%$ of injected radioactivity per liter of plasma) at time $\hat{\mathbf{t}}$. 
Because of the limited number of available data, we had to approximate MCR by the formula $1 / \sum_{1} x_{i} \Delta t_{i}$, where $x_{i}$ was mean $(3 \mathrm{H})$ androstenone during the time interval $\Delta \mathrm{t}_{\mathrm{i}}$. Assuming a two-pool distribution, MCR could also be obtained from the semi-log plot of the disappearance curve of plasma $\left({ }^{3} \mathrm{H}\right)$ androstenone (according to Tait and Burstein, 1964). The two approaches provided similar results.

\section{Results.}

\section{Profile of plasma radioactivity.}

The total radioactivity per liter of peripheral plasma increased during the first 14 min following $\left({ }^{3} \mathrm{H}\right)$ androstenone injection and declined afterwards (fig. 1), the

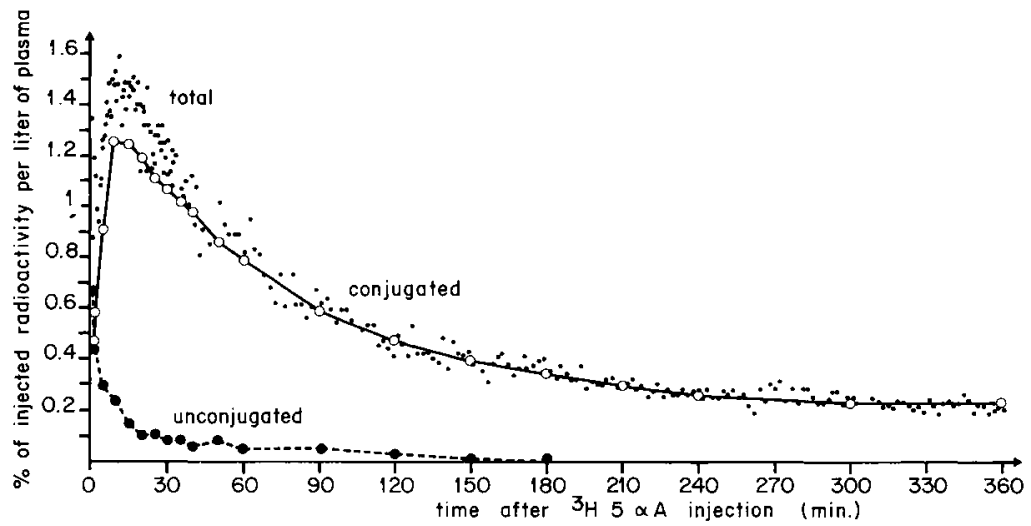

FIG. 1. - Profile of plasma radioactivity after injection of $\left({ }^{3} \mathrm{H}\right)$ androstenone.

maximal level being only $1.44 \%$ of the injected dose per liter. Plasma radioactivity decreased slowly: 250, 220, 140 and $13010^{3} \mathrm{dpm} / \mathrm{I}$ were measured $1,2,3$ and 7 days, respectively, after $\left({ }^{3} \mathrm{H}\right)$ androstenone injection. Radioactivity located in the unconjugated fraction declined very sharply after $\left({ }^{3} \mathrm{H}\right)$ androstenone injection. The absolute androstenone level as well as the percentage of this steroid in the unconjugated fraction decreased after radioactivity injection (fig. 2). The metabolic clearance rate of plasma androstenone was estimated at 87000 or 73000 liters per day, depending on whether the first or second method of calculation was used (fig. 3). The proportion of an- $\alpha$ and an $\beta$ declined slightly with time, whereas the percentage of the more polar compounds increased (fig. 2). There was no androstenone in the conjugated fraction which included only polar compounds from 30 min after injection. The metabolites of androstenone (an- $\alpha$, an- $\beta$ and polar compounds belonging to both fractions) accounted for $72 \%$ of plasma radioactivity as early 
as the first minute after injection. Afterwards, the proportion of these metabolites increased with time up to more than $99 \%$ of the total plasma radioactivity beyond $40 \mathrm{~min}$.

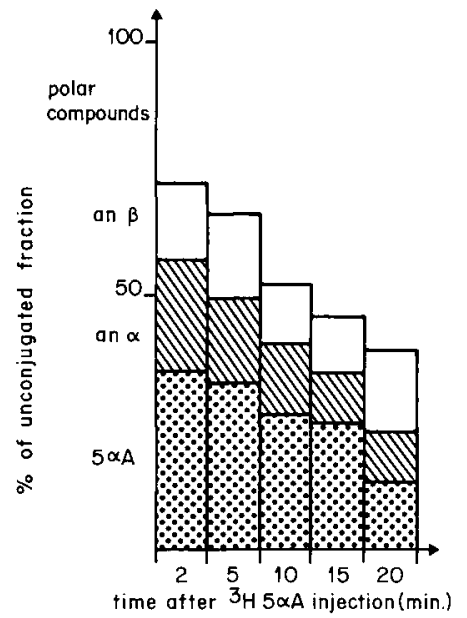

FIG. 2.

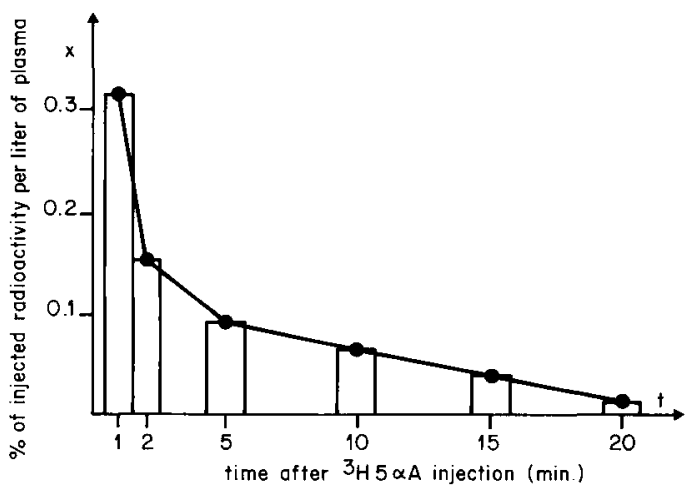

FIG. 3 .

FIG. 2. - Profile of the composition of plasma unconjugated fraction after injection of $\left({ }^{3} \mathrm{H}\right)$ androstenone.

FIG. 3. - Profile of plasma $\left({ }^{3} \mathrm{H}\right)$ androstenone after injection of $\left({ }^{3} \mathrm{H}\right)$ androstenone.

\section{Ways and forms of radioactivity elimination.}

Only a small quantity of the radioactivity was eliminated in the faeces. Faecal excretion accounted for $0.1,2.6$ and $1.8 \%$ of the injected dose on days 1, 2 and 3 , respectively, after injection.

Excretion of radioactivity in the urine of boar $A$ was maximal on day 1 (41\% of injected dose) and then declined. Only $51 \%$ of the injected dose was recovered in the urine after one week of collection. The elimination rate of boar $B$ appeared to be slower, maximal excretion being observed only on day 2 . The unconjugated fraction containing only polar compounds accounted for $30 \%$ of the urinary radioactivity on day 1 and for $15 \%$ on day 2 . Traces $(4 \%)$ of an- $\alpha$ and an- $\beta$ were found (on day 2 only) in the conjugated fraction, while the remaining radioactivity (96 to $100 \%$ ) was that of the polar compounds.

Thin-layer chromatography was performed on the hydrolized conjugated fraction of boar $B$ urine in order to investigate the nature of the polar compounds. Development with benzene-acetone (9/1) first confirmed that they differed from an- $\alpha$ and an- $\beta$. Further development with chloroform-ethanol $(9 / 1)$ separated these compounds into 3 zones; each zone was then individually developed with chloroform-ethanol $(7 / 3)$ but no further separation was obtained. 
The same 3 zones were obtained after thin-layer chromatography (chloroformethanol $9 / 1$ ) of the hydrolized conjugated fraction of plasma from boar A, 30 min and $60 \mathrm{~min}$ after $\left({ }^{3} \mathrm{H}\right)$ androstenone injection.

\section{Discussion.}

The profile of plasma radioactivity shows that androstenone injected into peripheral blood disappears quickly. Direct excretion into urine being excluded (Gower et al., 1970 a, b, 1972 ; Saat et al., 1974 and the present data), our results show that androstenone was catabolized into steroids belonging to both conjugated and unconjugated fractions. According to Fish et al. (1980), free $\mathrm{C}_{19} \Delta_{16}$ steroids may be conjugated in porcine liver. However, the metabolic clearance rate of androstenone is dramatically higher than hepatic blood flow (around 4000 liters per day in such animals). Therefore, other mechanisms are involved. The catabolism of androstenone by testes, described in in vitro (Gower, 1972) and in vivo (Saat et al., 1974) studies, cannot explain its quick disappearance from the plasma since testicular blood flow laround 30 liters per day according to Saat et al., 1974) was negligible compared to metabolic clearance rate. Consequently, we must assume that the uptake and storage of androstenone by the salivary glands and fatty tissue are the main mechanisms responsible for its very quick disappearance from the plasma.

The catabolism of androstenone leads to an- $\alpha$, an- $\beta$, and mainly to unidentified more polar compounds found in both plasma and urine. The presence of metabolites other than an- $\alpha$ or an- $\beta$ have been previously established in boar plasma (Saat et al., 1974) and human urine (Kingsbury and Brooksbank, 1978). However, the quantitative importance of these polar compounds appears to be an original result since they are the main form of androstenone elimination in the young boar. Previous results obtained in the mature boar (Gower et al., 1970 a, b, 1972 ; Saat et al., 1974) reported an- $\beta$ (mainly as glucuronide) and traces of an- $\alpha$ as the only forms of urinary excretion of androstenone. These conflicting results may be explained by differences in experimental techniques (injection into testicular artery vs peripheral venous plasma in our experiment) or by differences in the physiological age of the animals. Thus, as previously pointed out by Booth (1975) and Mason et al. (1979), the metabolism of $C_{19} \Delta_{16}$ steroids probably varies according to the age and the sexual maturity of the boars. The polar compounds found in this work were unidentified; it has only been shown that there are at least 3 different ones. They could be androstanetriols, as suggested by Kingsbury and Brooksbank (1978) in human studies, monoketoandrostanediols or diketoandrostaneols.

Only $51 \%$ of the injected radioactivity was recovered in urine after one week of collection, whereas a small proportion was eliminated in the faeces. The remaining radioactivity was probably still stored in body tissues since the apparent half-life of fat androstenone is in the range of 4 to 14 days in boars of similar age and weight (Claus, 1976 ; Bonneau et al., 1982). However, one cannot exclude the possibility that some $\Delta 4$ or $\Delta 5$ metabolites were formed, 
which could not be measured by the methods applied, since the $5 \alpha$-tritium labelling is removed in such compounds.

Our results were obtained in only one (MCR) or two boars lurinary excretion). Therefore, it would be worthwhile to confirm these preliminary findings and to try to identify the unknown polar compounds that are the main forms in which circulating androstenone is eliminated. Unfortunately, the limited availability of tritiated androstenone did not enable us to obtained any more data.

Reçu en septembre 1981. Accepté en mai 1983.

Résumé. Etudes sur le métabolisme de $5 \alpha$-androst-16-ene-3-one chez le jeune verrat in vivo.

Le métabolisme de $5 \alpha$-androst-16-ene-3-one (androsténone) plasmatique est étudié chez deux jeunes verrats pesant environ $100 \mathrm{~kg}$ chez qui une dose unique d'androsténone tritiée est injectée par voie intraveineuse. Pour l'un d'entre eux, du sang veineux périphérique est collecté en continu pendant $6 \mathrm{~h}$ après l'injection. La radioactivité totale par litre de plasma périphérique augmente jusqu'à 14 min après l'injection puis décroît assez lentement puisque la radioactivité plasmatique est encore mesurable après 7 jours. Le taux de clearance métabolique de l'androsténone plasmatique est d'environ 80000 litres par jour. Une disparition aussi rapide de l'androsténone plasmatique peut être expliquée par le stockage dans le tissu adipeux et, à un moindre degré, par le catabolisme vers $5 \alpha$-androst-16ene-3 $\alpha$-ol, $5 \alpha$-androst-16-ene- $3 \beta$-ol et surtout vers des composés plus polaires non identifiés (au moins 3 différents). La radioactivité est essentiellement éliminée dans les urines sous la forme des mêmes composés polaires.

\section{Références}

BICKNELL D. C., GOWER D. B., 1975. Separation of some 16-androstenes on hydroxyalkoxypropyl-Sephadex (Lipidex). J. Chromatogr., 110, 210-212.

BOOTH W. D., 1975. Changes with age in the occurence of $C_{19}$ steroids in the testis and submaxillary gland of the boar. J. Reprod. Fert., 42, 459-472.

BONNEAU M., MEUSY-DESSOLLE N., LÉGLISE P. C., CLAUS R., 1982. Relationships between fat and plasma androstenone and plasma testosterone in fatty and lean young boars following castration. Acta endocrinol. (Copenh), 101, 129-133.

BROPHY P. J., GOWER D. B., 1973. Further studies on the properties of the Enzyme System involved in the conversion of $C_{31}$ steroids into 16 unsaturated $C_{19}$ steroids in boar testis. Biochem. Soc. Trans., 1, 181-184.

BROPHY P. J., GOWER D. B., 1974. Studies on the inhibition by $5 \alpha$-Pregnane-3,20-dione of the biosynthesis of 16-androstenes and dehydroepiandrosterone in boar testis preparations. Biochim. biophys. Acta, 360, 252-259.

CLAUS R., 1976. Messung des Ebergeruchstoffes im Fett von Schweinen mittels eines Radioimmunotests. 2. Mitteilung : Zeitlicher Verlauf des Geruchdepotabbaues nach der Kastration. Z. Tierz. Züchtungsbiol., 93, 38-47.

CLAUS R., 1979. Pheromone bei Säugetieren unter besonderer Berüchsichtigung des Ebergeruchstoffes und seiner Beziehung zu anderen Hodensteroiden. In Forstchr. Tierphysiol. Tierernähr, $\mathrm{n}^{\circ} 10$ (Beihefte zur $\mathrm{Z}$. Tierphysiol. Tierernähr. Futtermittelkd), P. Parey Verlag, $136 \mathrm{pp}$.

FISH D. E., COOKE G. M., GOWER D. B., 1980. Investigation into the sulfoconjugation of $5 \alpha$-androst-16-en-3 $\beta$-ol by porcine liver. Febs Lett., 117, 28-32. 
GOWER D. B., 1972. 16 unsaturated $C_{19}$ steroids : a review of their chemistry biochemistry and possible physiological role. J. Steroid Biochem., 3, 45-103.

GOWER D. B., HARRISSON F. A., HEAP R. B., PATTERSON R. L. S., 1970a. The identification of $C_{19} \Delta_{16}$ steroids in boar urine and spermatic vein plasma. $J$. Endocrinol., 46, 18-19.

GOWER D. B., HARRISSON F. A., HEAP R. B., 1970b. The identification of $\mathrm{C}_{19} \Delta_{16}$ unsaturated steroids and estimation of 17 oxosteroids in boar spermatic vein plasma and urine. J. Endocrinol., 47, 357-368.

GOWER D. B., HARRISSON F. A., HEAP R. B., SAAT Y. A., 1972. Studies on the in vivo biosynthesis and excretion of $\mathrm{C}_{19} \Delta_{16}$ unsaturated steroids in the boar. $J$. Endocrinol., 52, iil-iv.

KINGSBURY A. E., BROOKSBANK B. W. L., 1978. The metabolism in man of $(3 \mathrm{H})-5 \alpha-16-$ androsten-3 $\alpha$-ol an of ( $\left.{ }^{3} \mathrm{H}\right)-5 \alpha$-16-androsten-3-one. Hormone Res., 9. 254-270.

MASON J. I., PARK R. J., BOYD G. S., 1979. A novel pathway of androst-16-ene Biosynthesis in immature pig testis microsomal fractions. Biochem. Soc. Trans., 7, 641-643.

SAAT Y. A., GOWER D. B., HARRISSON F. A., HEAP R. B., 1972. Studies on the biosynthesis in vivo and excretion of 16 unsaturated $C_{19}$ steroids in the boar. Biochem. J., $129,657-663$.

SAAT Y. A., GOWER D. B., HARRISSON F. A., HEAP R. B., 1974. Studies on the metabolism of $5 \alpha$-androst-16-en-3-one in boar testis in vivo. Biochem. J., 144, 347-352.

SHIMIZU K., NAKADA F., 1976. Formation of $\left(17 .{ }^{2} \mathrm{H}\right)$ androsta-5, 16 -dien-3 $\beta$-ol from $(17,21,21$, 21) pregnenolone by the microsomal fraction of boar testis, Biochim. biophys. Acta, 450 , 441-449.

TAIT J. F., BURSTEIN S., 1964. In vivo studies of steroid dynamics in man, 441-557. In G. PINCUS, K. V. THIMANN, E. B. ASTWOOD. The hormones, vol. V, Acad. Press, New York. 